\title{
The occlusion of opinion: incitement to religious hatred
}

by Paul Kearns

The author considers the controversial issues germane to the proposed new offence in English domestic law of incitement to religious hatred. Whether or not a relevant piece of legislation that is appropriately formulated eventually comes into force, the underlying issues presented here will continue to be voiced and revisited in legal, political, social and private contexts.

\section{INTRODUCTION}

I ncitement to religious hatred, which will still feasibly become a new crime, is still in its incipient stages of development at the time of writing, and was first proposed by the former Home Secretary David Blunkett as part of his more general legal reform plans. The central idea behind the offence is that it would supersede the ancient offence of blasphemous libel and simultaneously supplement the existing public order offence of incitement to racial hatred. One policy reason for instituting this new offence rests on the surprising reality that Muslims are currently unprotected under the laws relating to the protection of public order because they are deemed by the existing legal wisdom to comprise a religious rather than a racial group. They are thus unprotected under the crime of incitement to racial hatred because they do not constitute a race, and, in addition, go unprotected under the extant blasphemy law because blasphemy in the United Kingdom only protects from vilification the Christian religion, more particularly Anglicanism.

A new crime of incitement to religious hatred would arguably remedy the adverse position of Muslims in out multi-cultural society by providing a new offence protecting religious groups, particularly minorities, which would co-extensively lead to the concomitant, automatic repeal of our now outmoded blasphemy law which anachronistically protects only Christianity in our contemporary postmodern, religiously-plural, nationalsocial environment. The new crime would also, naturally, have the advantage over blasphemy law of protecting other small religious minority groups. The price for this innovative reform appears to some the sacrifice of freedom of expression in the United Kingdom. This fear is sadly enhanced by the opaque image of incitement to religious hatred as far as the public is concerned. The constituent elements of the proposed new offence have not been sufficiently transparent to satisfy critics that a draconian limit on free speech is not going to be indirectly achieved.

\section{THE HISTORY OF THE PREVAILING DEBATE}

The evolution of the proposed new law has been somewhat haphazard. On July 7, 2004, a fresh attempt to outlaw acts of religious hatred was made by Mr Blunkett because an earlier directly-comparable change in the law had been abandoned in 2001 after claims that it would be unworkable. The 2004 initiative framed the law in terms of a criminal offence of inciting hatred against groups or individuals on the grounds of their beliefs. This would carry a maximum seven years in jail. The earlier 2001 proposal was conceived as part of anti-terrorist legislation and had been denounced as an attack on free speech, prompting fears from Rowan Atkinson and other comedians that they could be prosecuted for lampooning religious figures. It provided no definition of "religious belief" or of "religion", and even by 2004 many ministers still believed that such a law was unnecessary. The harshest critics said that the planned legislation in both 2001 and 2004 would prove divisive and impractical, and was being offered as "a sop" to the Muslim community, which was allegedly feeling vulnerable after the events of the notorious September 11.

However, in reality Muslims have been pressing for an incitement law for many years. As alluded to above, unlike Sikhs and Jews, for example, Muslims are not covered by racial hatred laws, and a Lords select committee comparatively recently opined that the same standards of protection should be afforded to all religions. But past governments have taken the view that most cases of incitement against Muslims could be dealt with by existing laws. Tough penalties do exist for religiously-motivated aggravated assaults, but with only a handful of resultant convictions. Despite this paucity, it has been persistently argued that freedom of speech and expression should only be curtailed when there is a likelihood and intention to threaten public order. Such advocates think it inappropriate to punish those who merely offend others' religious sensibilities. By 2004, Mr Blunkett was ready to 
affirm that the offence would be designed to deal with those who deliberately stir up dissension and hate and not those who criticise beliefs with which they disagree. The then government believed it possible to make such a distinction in law; it also believed that the new offence could be used against fundamentalist Islamist preachers as well as protecting Muslims from attacks. On July 6, 2004, a meeting of EU interior ministers, chaired by Mr Blunkett at Hassop Hall, Derbyshire, agreed that militant Islamic groups should face a ban across Europe to help combat the threat from al-Qa'eda.

Otto Schily, Germany's interior minister, called for a common approach towards groups that constitute "a threat to society", including restrictions on freedom of association. One fundamentalist organisation had been banned in Germany because its "objectives did not tally with our constitution", he said. He continued, "It won't do if the same thing is not then banned in a neighbouring country. We have to act in harmony." From a British perspective, Britain operates a proscription list containing the names of several Islamist organisations, including alQa'eda. It is illegal to support a group on the list, raise funds for it or attend its meetings. Under the German proposal, any group banned in one country would be proscribed in the rest of the EU. The summit agreed the need to harmonise police, counter-terrorism and border control measures to stifle support for fundamentalists.

In the light of anti-terrorist rhetoric, inciting religious hatred as a crime could be viewed as a counter-measure, inviting political activists against Britain's better interests to chant their aggressive creeds. For this and other reasons, by December 8th 2004, David Blunkett faced a growing revolt over plans to make incitement to religious hatred an offence. On December 7, 2004, MPs from all parties denounced the measure, which has been condemned by legal experts, Christians, secular organisations, writers, and, as previously mentioned, comedians. To appease the measure's critics, Mr Blunkett then tried to set out the circumstances in which the law could be used. He asserted that the offence would not criminalise material that just stirs up ridicule, prejudice, dislike, contempt or anger or which simply causes offence. He urged that a person who does not intend to stir up hatred is not guilty if he or she does not know that their words, behaviour, written material, recording or programmes were threatening, abusive or insulting. Moreover, he pointed out that the medley of envisaged associated offences on the religious incitement theme would not apply to anything that takes place in one's own home. To prevent misuse through private prosecutions, all prosecutions would require the consent of the Attorney General.

The critics were not impressed, not least because, with the lack of a definition in the putative offence of the word "religion", the wording of the crime contemplated was still too loose, and thus represented a clear threat to free speech. David Davis, the then shadow home secretary, said:
"This legislation will curb freedom of speech without any benefit being realised. Evil ideas should be met with challenge. The best remedy for evil ideas is more speech not less." Labour backbenchers also lined up to criticise the Bill as Liberal Democrats warned that it was likely to be rejected in both the Commons and the Lords. Jon Owen Jones, Labour MP for Cardiff Central, said: "Some of us are very concerned about legislating about religious belief. There is a real danger that if one looks at religious tracts one will find many reasons in this Bill to prosecute people for their religious beliefs." Robert MarshallAndrews, Labour MP for Medway, said: "I have very grave doubts as to whether it should be criminal, as opposed to merely socially unacceptable, to incite hatred against someone because of what we do; and religion is what we do and not what we are."

However, as W B Yeats, the late Irish poet, might proffer, "Who can tell the dancer from the dance?". This quotation usefully points us to the central underlying problem with the proposed new offence, viz that its very object is ambiguous, and too conceptually indistinct to be legislated on successfully, let alone to everyone's factual satisfaction.

\section{FURTHER CONSIDERATIONS}

Apart from such observations by politicians, there are several other germane factors and arguments that contribute to the debate on incitement to religious hatred's legal, conceptual and practical viability. $\mathrm{Mr}$ Blunkett envisaged that the proposed law would cover both hatred of a particular religion and hatred arising from a religion. Because of this, it may be difficult to ascertain who is being religiously intolerant in a confrontation between two proponents of different belief systems, such as a conservative Anglican and a homosexual rights campaigner. It is also arguable that the policy emphasis in any liberal society should centre on policing action and not policing thought, on crime and not controlling minds. And yet in the era of strict political correctness, it is unsurprising if lamentable that the focus of governmental control sometimes has individual psyches rather than actual devious practice as its target.

Some argue that it is simply not the business of government to determine ethical issues connected with the often long-held belief of individuals; and it is very difficult to establish when the legitimate expression of fundamentally incompatible faiths carries over into incitement to "religious hatred". Others are cynical about exactly why Mr Blunkett slipped into the Serious Organised Crime and Police Bill measures extending to cover a religious form of hatred. As stated previously, whereas mono-ethnic "faith groups", such as Jews and Sikhs, are already protected by laws against racial incitement, that law does not currently cover multi-ethnic "faith groups" such as Muslims. The cynical maintain that the religious incitement measure is an attempt by New 
Labour to claw back Muslim support that was squandered through the war in Iraq.

According to some, the proposed law will inhibit religious debate and stifle legitimate criticism of religious groups including, ironically, general objections to religious practice on the whole, on the grounds that it causes unnecessary inter-personal and inter-group hostility. In view of such observations, it might have been prudent and helpful to insert into the relevant Bill a section that unequivocally states that scholarly open debate on religion and matters consequential to religious belief and practice should be fostered in schools, colleges and universities. Such open exchange was the very keystone of Periclean Athens, which forms the basis of the modern democratic ideal. Surely such interaction in the public arena must be preferable to the present proposal, which one feels can only provoke and promote prejudiced opinion in clandestine ghettos.

On March 5, 2005, the then Minister for Racial Equality said in a letter to the Times newspaper that the same routine arguments as those offered against the proposed new crime of stirring up religious hatred had been offered in debates since the 1960s against provisions on incitement to racial hatred. This is not completely so, because a person cannot choose his or her race, but is free to choose a religion. The Minister also said that the new law would not proscribe criticism of religious beliefs; but if one criticises a person's religious beliefs by saying they are barbaric, cruel, superstitious, intolerant and anti-social, one can plausibly be accused of stirring up hatred against that person. Practical problems also arise in connection with the proposed offence. The police will be the ones who make the initial decision to investigate an allegation, arrest suspects and seize property. A legitimate query is whether the government plans to train the police in the nuances of comparative theology.

The proposed legislation is sometimes justified by the perceived necessity to tackle "extremists", such as those involved in the 2001 domestic riots. However, the government has so far failed to provide a single specific example of any words or behaviour which could not be prosecuted under existing law and which could and should be prosecuted under the proposed new law. What constitutes "incitement" is a matter of subjective opinion, and any judicial decisions where the notoriously subjective area of religion is in issue are arguably destined to be commensurately subjective. The matter is further complicated by the character of the alleged incitement. Salman Rushdie's novel, The Satanic Verses, is a work of fiction that could hypothetically be caught by the terms of the proposed new law as stirring up hatred against Islam. But what about freedom of artistic expression, which is culturally and ontologically distinct as a process, and only relates to any alleged offensiveness obliquely, since art is symbolic not literal ? It is arguable that, in some respects, a law against religious hatred is, in effect, an invitation to commit it. It incites each faith to take offence, and ensures that the most zealous can make the most trouble.

Criminalising incitement to religious hatred could increase intolerance and hatred if used by different groups as a weapon against each other, cause the deterioration of good relations between different groups and hinder the enforcement of law and order. If the government is really interested in "strength in diversity", community cohesion and race equality, the optimal route is probably to allow people to express their religious belies freely and without fear. Moreover, there are lessons to be learnt from abroad. On December18, 2004, in Victoria, Australia, two Christian clerics were convicted of violating the Racial and Religious Tolerance Act 2004. The facts were as follows. Two months after the statute's enactment, Daniel Scot and Pastor Danny Nalliah conducted a Melbourne seminar on Islam. As a matter of concrete fact, Daniel was born in Pakistan, is an authority in Islamic studies, and translates the Koran from the Arabic. Three Australian converts to Islam attended the seminar and took notes. Not long afterwards, the Islamic Council of Victoria made a formal complaint of vilification against them. The scholars were subsequently found guilty of violating the new law, in part because they read passages of the Koran that the complainants claimed vilified them.

\section{CONCLUDING OBSERVATIONS}

Freedom of speech and expression, as fashioned in the West, includes the right to offend. One example of tolerating alleged offence is quite striking, and unfortunately ironic, and demonstrates that it is not only Muslims who can be affronted in accordance with their religious sensibilities. According to Randhir Singh Bains, it is the right to offend that has so far prevented Hindus from formulating a dispute over a verse in the Koran (Verse 39, Chapter 8) that urges "Muslims to make war on idolworshippers (Hindus) until idolatry is no more and Allah's religion reigns supreme". Should a law against incitement to religious hatred be enacted, however, Hindus would be free from such self-imposed constraints, and would be perfectly within their legal and moral rights to insist that such apparently "offensive" verses, which could be construed as illegal under the proposed new law, should to be expunged from the Koran. Unlikely and undesirable though this may be, it raises very serious concerns of an inter-faith confrontational problematic that could escalate under a new law of incitement to religious hatred. But the immediate example shifts attention away from, and arguably detracts from, the relevance of the particularly Muslim dilemma in the context of the proposed new law. All religious groups experience the contempt for, ignorance of, and lack of interest in religious belief and practice in contemporary, largely secular Britain, but it weighs particularly heavily on Muslims, whose international community is desperately economically deprived (70\% of 
Pakistani and Bangladeshi children live in poverty), and increasingly adversely affected by anti-terrorist legislation.

Very sadly, the proposed law of incitement to religious hatred would not lead to an increased respect for Islam because the law as currently framed is such a potential curtailment of free speech, the right that the West upholds as the cardinal right. Nevertheless, a comparable law could and should be enacted which at least protects the Muslim way of life in a similar way to the one that safeguards the security of Jewish and Sikh communities in Britain without seeming to compromise freedom of opinion. Not to address the very particular Muslim plight is a recipe for perpetuating Muslim dissatisfaction with a British sense of justice that so cruelly neglects the necessities of Islam, a lacuna in social duty which could ultimately lead to Britain's ineluctable, more precarious detriment in the wider world. As Iqbal Sacranie has so cogently said, "Muslims in Britain do not seek to create an enclave or a parallel culture. They want to be respected as British. That is what they are. And the government that sees and treats them as such, by criminalising offences directed specifically at them, is a government that understands its obligations."
Nevertheless, on May 17, 2005, Don Horrocks, head of public affairs at the Evangelical Alliance, said, "We still consider that this legislation is likely to undermine freedom of speech, damage community relations, and usher in a new climate of liberalism and repression." Despite this, the current Home Secretary, Charles Clarke, maintains, at the time of writing, that the Government will use the Parliament Act, if necessary, to force through an Incitement to Religious Hatred Bill, thereby overcoming the already proven opposition of the House of Lords. This is not necessarily wise, because, as the Lords contend, the measure will clearly inescapably compromise free speech in one way or another. The envisaged law will preclude open debate on serious issues, including religion, in favour of a potentially lethal gagging device of Orwellian prediction and dimension, palpably unwelcome and unworkable in any true democracy of western inspiration. 숭

\section{Dr Paul Kearns}

The author is a Lecturer in Law at the School of Law, University of Manchester, where he specialises in freedom of speech. 